The City in Literature 



\section{The City in Literature}

An Intellectual

and Cultural History

Richard Lehan

UNIVERSITY OF CALIFORNIA PRESS

Berkeley / Los Angeles / London 
University of California Press

Berkeley and Los Angeles, California

University of California Press, Ltd.

London, England

(C) 1998 by

The Regents of the University of California

Library of Congress Cataloging-in-Publication Data

Lehan, Richard Daniel, 1930-

The city in literature : an intellectual and cultural history /

Richard Lehan.

p. $\mathrm{cm}$.

Includes bibliographic references and index.

ISBN 0-520-21042-5 (hardcover : alk. paper). -

ISBN 0-520-21256-8 (pbk. - alk. paper)

I. Cities and towns in literature. 2. Literature, ModernHistory and criticism. I. Title.

PNs6.CssL44 1998

$809^{\prime} 93321732-\mathrm{dc} 21$

97-3443

Printed in the United States of America

$\begin{array}{lllllllll}9 & 8 & 7 & 6 & 5 & 4 & 3 & 2 & 1\end{array}$

The paper used in this publication meets the minimum requirements of American National Standard for Information Sciences-Permanence of Paper for Printed Library Materials, ANSI Z39.48-I984. 
In memory of

Edward Scott Lehan

To

thE city he

loveD

and the

citr

be neper knew 

Over the great bridge ... with the city rising up across the river in white heaps and sugar lumps all built with a wish out of non-olfactory money. The city seen from the Queensboro Bridge is always the city seen for the first time, in its first wild promise of all the mystery and the beauty in the world.

A dead man passed us in a hearse heaped with blooms.

F. Scott Fizgerald

When the stanger says: "What is the meaning of this city?

Do you huddle close together because you love each other?"

What will you answer? "We all dwell together

To make money from each other"?

T. S. Eliot

The police force would have to be doubled when the stars started to arrive. At the sight of their heroes and heroines, the crowd would turn demoniac. ... New groups, whole families, kept arriving. He could see a change come over them as soon as they had become part of the crowd. ... It was a mistake to think them harmless curiosity seekers. They were savage and bitter, especially the middle-aged and old, and had been made so by boredom and disappointment. ... They realize that they've been tricked and burn with resentment. Every day of their lives they read the newspapers and went to the movies. Both fed them on lynchings, murder, sex crimes, explosions, wrecks, love nests, fires, miracles, revolutions, wars. ... Nothing can ever be violent enough to make taut their slack minds and bodies.

Nathanael West

Lo! Death has reared himself a throne

In a strange city lying alone

Far down within the dim West[.]

Edgar Allan Poe 
